Friedrich K. Pühringer MD, Philipp Keller C M,

Alexander Löckinger MD, Axel Kleinsasser MD, Annkatrin Scheller CM, Claus Raedler CM, Christian Keller MD

\section{Smoking does not alter the dose-requirements and the pharmacody- namics of rocuronium}

Purpose: Controversial data about the effect of smoking on the dose-requirements and the pharamcodynamics of rocuronium have been reported recently. This study was conducted to evaluate the dose-requirements and the pharmacodynamics of rocuronium in smokers using target controlled infusion.

Methods: The dose-requirements of rocuronium for 60 min relaxation, using target controlled infusion, given under intravenous anaesthesia with propofol, fentanyl and nitrous oxide was studied in 37 smokers and 37 nonsmokers. Initially $450 \mu \mathrm{g}_{\mathrm{kg}}{ }^{-1}$ rocuronium were administered, neuromuscular effects were quantified by recording the single twitch response of the adductor pollicis muscle after ulnar nerve stimulation using a force transducer, and the neuromuscular block was kept at $80 \%$ by target controlled infusion throughout the procedure.

Results: The dose-requirements for one hour relaxation were $867 \pm 116 \mu \mathrm{g}^{-1} \mathrm{gg}^{-1} \cdot \mathrm{hr}^{-1}$ for smokers (S) and 839 $\pm 149 \mu \mathrm{g} \cdot \mathrm{kg}^{-1} \cdot \mathrm{hr}^{-1}$ for non-smokers (NS). The duration to $10 \%$ and the spontaneous recovery from $25 \%$ to $75 \%$ of the control twitch response also showed no differences between $\mathrm{S}(17.2 \pm 3.4 \mathrm{~min}, 10.6 \pm 0.9 \mathrm{~min})$ and NS ( $18.9 \pm 4.3 \mathrm{~min}, 10.9 \pm 3.2 \mathrm{~min}$ ), as well as maximum block, onset time and infusion rate.

Conclusion: Smoking does not alter the dose-requirements for rocuronium and no effects on the onset time, degree of block, time to maximum block, duration 10\% and spontaneous recovery index were observed.

Objectif: Des données controversées au sujet de l'effet du tabagisme sur les doses nécessaires de rocuronium et sur sa pharmacodynamie ont été publiées récemment. La présente étude a été menée pour évaluer les doses efficaces de rocuronium et sa pharmacodynamie chez des fumeurs en utilisant une perfusion cible contrôlée.

Méthode : Les doses de rocuronium nécessaires pour provoquer un relâchement musculaire de 60 min ont été étudiées chez 37 fumeurs et 37 non fumeurs, à l'aide d'une perfusion cible contrôlée. Elles ont été administrées sous anesthésie intraveineuse avec du propofol, du fentanyl et du protoxyde d'azote. On a d'abord administré $450 \mu \mathrm{g} \cdot \mathrm{kg}^{-1}$ de rocuronium, puis on a quantifié les effets neuromusculaires en enregistrant les contractions uniques de l'adducteur du pouce après la stimulation du nerf cubital à l'aide d'un transducteur de force. Le blocage neuromusculaire a été maintenu à $80 \%$ par la perfusion cible contrôlée tout au long de l'intervention.

Résultats : Les doses requises pour assurer une heure de myorelaxation ont été de $867 \pm 116 \mu \mathrm{g}^{\mathrm{k}} \mathrm{kg}^{-1 \cdot \mathrm{h}^{-1}} \mathrm{chez}$ les fumeurs (F) et de $839 \pm 149 \mu \mathrm{g} \cdot \mathrm{kg}^{-1} \cdot \mathrm{h}^{-1}$ chez les non fumeurs (NF), $P$ : NS. Le temps d'atteindre $10 \% \mathrm{du}$ bloc et la récupération spontanée de $25 \%$ à $75 \%$ des réponses par contractions contrôlées n'ont pas présenté de différences entre les patients du groupe $F(17,2 \pm 3,4 \mathrm{~min}, 10,6 \pm 0,9 \mathrm{~min})$ et ceux du groupe NF (18,9 \pm $4,3 \mathrm{~min}, 10,9 \pm 3,2 \mathrm{~min}$ ). Aucune différence n'est apparue pour le temps nécessaire à l'obtention du bloc maximal, le délai d'installation du bloc et le débit de la perfusion.

Conclusion : L'habitude de fumer ne modifie pas les besoins de rocuronium. Aucun effet sur le délai d'installation du bloc, le degré, le temps d'atteindre le bloc maximal, la durée du bloc à $10 \%$ et l'indice de récupération spontanée n’a été observé.

From the Department of Anaesthesia and General Intensive Care Medicine, University of Innsbruck, Anichstrasse 35, A-6020 Innsbruck, Austria.

Address correspondence to: Univ. Prof. Dr. Friedrich K. Pühringer. Phone: 43-512-504-4319; Fax: 43-512-504-2450; E-mail:

friedrich.puehringer@uibk.ac.at

This study was supported in part by a grant from Organon GesmbH, Division Organon Teknika, Vienna, Austria.

This study has been presented in parts at the 73rd IARS Meeting in Los Angeles, California, in March 12-16, 1999.

Accepted for publication January 16, 2000

CAN J ANESTH 2000/47: 4 / pp 347-349 


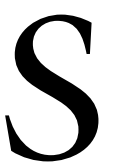
MOKING can alter the pharmacodynamics of various drugs. ${ }^{1}$ The effect of smoking on the potency of neuromuscular blocking drugs is controversial. For atracurium a greater sensitivity in smokers has been observed. ${ }^{2}$ In contrast the dose of vecuronium to maintain the same level of neuromuscular block was increased by $25 \%$ in smokers. ${ }^{3}$ In a recent study a statistically borderline increase in the dose-requirements of rocuronium in smokers was reported. ${ }^{4}$ Latorre ${ }^{5}$ reported pharmacodynamic data showing numnerically large differences between smokeres and non-smokers which seemed to be of clinical relevance, but they did not reach statistically significance.

The aim of this study was to evaluate the pharmacodynamics and the dose-requirements for rocuronium whilst maintaining $80 \%$ neuromuscular block for 60 min using target controlled infusion in smokers and non-smokers.

\section{Methods}

Following approval by the Ethics Committee in Innsbruck, and a sample size estimate with power $=0.9$ ), based on the data provided by Latorre, ${ }^{5} 74$ consenting ASA class I or II patients, of normal weight, between 18 and $65 \mathrm{yr}$, scheduled for elective gynecological or orthopedic surgery of an expected duration of $90 \mathrm{~min}$ were included. Thirty-seven were smokers, (>20 cigarettes per day) during the last five years, the others were non-smokers. Patients known to have neuromuscular disorders, metabolic disease, impaired kidney or liver function, or taking medication known to alter neuromuscular transmission were excluded. All patients received $7.5 \mathrm{mg}$ midazolam po as premedication approximately one hour before induction of anesthesia.

Anesthesia was induced using $3 \mu \mathrm{g} \cdot \mathrm{kg}^{-1}$ fentanyl and $2.5 \mathrm{mg} \cdot \mathrm{kg}^{-1}$ propofol $i v$ and maintained by controlled ventilation with $2: 1 \mathrm{~N} 2 \mathrm{O} /$ oxygen and continuous infusion of propofol $\left(4-5 \mathrm{mg} \cdot \mathrm{kg}^{-1} \cdot \mathrm{hr}^{-1}\right)$. The airway was maintained with a Laryngeal Mask Airway (LMA). Then, assessment of neuromuscular transmission was commenced. Recordings of the single twitch contractions of the adductor pollicis muscle were obtained by stimulating the ulnar nerve at the wrist using surface electrodes with supramaximal squarewave stimuli of $0.2 \mathrm{msec}$ duration at a frequency of $0.1 \mathrm{~Hz}$. The resultant force of thumb adduction was quantified via a force displacement transducer after applying a resting tension of $200-400 \mathrm{~g}$ and recorded via a Relaxometer $2^{6}$ and calculated using a closed loop infusion computer program with an algorithm included. The closed-loop control system is based on a fuzzy logic system and consists of 32 fuzzy rules inferencing over three inputs (error, relaxation rate of change, relaxation stability). The membership functions of the controller were optimized in simulation for maximum performance over 150 randomly generated PK/PD models. Every $10 \mathrm{sec}$, in accordance with the last twitch response the infusion rate was adjusted automatically. Ventilation was controlled during determination of the maximal twitch response and the supramaximal stimulation current. After a stable twitch response was obtained for approximately ten minutes an initial bolus of $450 \mu \mathrm{g} \cdot \mathrm{kg}^{-1}$ rocuronium was administered by the infusion pump over $30 \mathrm{sec}$.

Skin temperature at the site of the surface electrodes was monitored and recorded continuously with the Relaxometer $2^{6}$ and kept $>33.0^{\circ} \mathrm{C}$.

Neuromuscular monitoring was continued throughout the operation and all patients recovered spontaneously from the neuromuscular block after 60 min relaxation. In assessing neuromuscular effects, we measured dose-requirements $\left(\mu \mathrm{g} \cdot \mathrm{kg}^{-1} \cdot \mathrm{hr}^{-1}\right)$, infusion rates, maximum block after initial bolus, onset time (time from end of the initial bolus until 95\% block), time to maximum block, duration $10 \%$ (time from initial bolus until $10 \%$ recovery of control twitch height) and the spontaneous recovery index (time between $25 \%$ and $75 \%$ recovery of control of twitch height).

Neuromuscular data and demographic characteristics between the two groups were compared using Student's $t$ test. The analysis of gender was performed using the Chi-Square test. Differences were considered significant at $P<0.05$. All values are given as mean \pm SD.

Results

Demographic data were comparable between the groups (Table I). The dose-requirements per hour relaxation, the infusion rates, onset times, maximum block, time to maximum block, duration $10 \%$ and the spontaneous recovery index are presented in Table II.

\section{Discussion}

The dose-requirements, maximum block, onset time, time to maximum block, duration $10 \%$ and the spontaneous recovery index did not differ between smokers and non-smokers.

These findings are in contrast to previous observations indicating increased requirements for rocuronium in smokers. ${ }^{4}$ Rautoma ${ }^{4}$ investigated only 20 patients per group, using EMG measuring NMB with stimulation every $20 \mathrm{sec}$ and provided a relatively wide range of NMB (90\%-99\%) using bolus administrations. In contrast, we investigated 74 patients and per- 
TABLE I Demographic data (given as mean \pm SD)

\begin{tabular}{lll}
\hline & Smokers & Non-Smokers \\
\hline Age $(\mathrm{yr})$ & $34 \pm 11$ & $33 \pm 9$ \\
Weight $(\mathrm{kg})$ & $70 \pm 10$ & $73 \pm 11$ \\
Height $(\mathrm{cm})$ & $172 \pm 11$ & $176 \pm 9$ \\
Male $/$ female & $23 / 14$ & $25 / 12$ \\
\hline
\end{tabular}

TABLE II Hourly dose-requirements and pharmacodynamic data of rocuronium in smokers and non-smokers.

\begin{tabular}{lll}
\hline & Smokers & Non-Smokers \\
\hline Dose requirements $\left(\mu \mathrm{g} \cdot \mathrm{kg}^{-1} \cdot \mathrm{hr}^{-1}\right)$ & $867 \pm 116$ & $839 \pm 149$ \\
$\quad$ median & 870 & 828 \\
$\quad$ range & $714-1125$ & $607-1485$ \\
infusion rate $\left(\mathrm{ml} \cdot \mathrm{hr}^{-1}\right)$ & $20.0 \pm 4.6$ & $20.5 \pm 6.5$ \\
spontaneous recovery $(\mathrm{min})$ & $10.6 \pm 3.3$ & $10.9 \pm 3.2$ \\
maximum block $\%)$ & $98 \pm 4$ & $98 \pm 3$ \\
time to max. block $(\mathrm{sec})$ & $305 \pm 92$ & $301 \pm 108$ \\
onset time $(\mathrm{sec})$ & $154 \pm 88$ & $157 \pm 91$ \\
duration $10 \%(\mathrm{~min})$ & $17.2 \pm 3.4$ & $18.9 \pm 4.3$ \\
\hline
\end{tabular}

formed a more precise technique using mechanomyography with target controlled infusion, adjusting the infusion rate automatically every $10 \mathrm{sec}$ in accordance with the last twitch height and maintaining NMB constant at $80 \%$. Nevertheless, Rautoma presented only statistically borderline differences in the dose-requirements concluding an increased dose-requirement for smokers, most likely due to increased metabolism. On the other hand they did not find any differences in the $\mathrm{ED}_{95}$ for smokers and non-smokers. ${ }^{4}$ This supports our findings and it is conceivable, that their technique, stimulation only every $20 \mathrm{sec}$ and bolus administrations of rocuronium, to maintain a relatively wide range (90\%-99\%) of NMB was responsible for the observed differences in the dose-requirements.

Recently, atracurium-induced neuromuscular block in smokers was investigated. ${ }^{2}$ Smokers who refrained from smoking for more than ten hours showed, in contrast to smokers who refrained from smoking for only one to three hours, a delayed recovery and required smaller maintenance doses. This was explained by interaction of acetylcholine and nicotine at the neuromuscular junction, where the chronic presence of nicotine might decrease the number of acetylcholine receptors. Therefore, less relaxant is needed to cover the depressed number of receptors. Chronic presence of nicotine may down-regulate the production of acetylcholine. Low concentrations of nicotine could explain the reduced dose of atracurium in the more than ten hours refrain- ing group. ${ }^{2}$ Nevertheless, in our study, all smokers refrained from smoking for more than ten hours and we were not able to detect any differences. This relates favourably with Latorre's data, ${ }^{5}$ showing unaltered pharmacodynamics after rocuronium in smokers. However, a decrease in the duration $25 \%$ and duration $75 \%$ in smokers was reported, ${ }^{5}$ but the differences did not reach statistical significance, probably related to the small number of patients. Nevertheless, the differences in Latorre's study ${ }^{5}$ (duration 25\%: $28 \pm 15 \min (S)$ vs $41 \pm 14 \mathrm{~min}(\mathrm{NS})$; duration $75 \%: 40 \pm 20 \mathrm{~min}(\mathrm{~S})$ vs 58 \pm 28 min seem large, although the anesthesia technique might be responsible. Anesthesia was maintained with variable concentrations of enflurane, known to alter the pharmacodynamics of muscle-relaxants.

Our data indicate that smoking does not alter the dose-requirements and the pharmacodynamics of rocuronium.

\section{References}

1 Dawson GW, Vestal RE. Smoking and drug metabolism. Pharmacol Ther 1982; 15: 207-21.

2 Purra AIE, Rorarius MGF, Laippala P, Baer GA Does abstinence from smoking or a transdermal nicotine system influence atracurium-induced neuromuscular block? Anesth Analg 1998; 87: 430-3.

3 Teiriä H, Rantoma P, Yli-Hankala A Effect of smoking on dose requirements for vecuronium. $\mathrm{Br} \mathrm{J}$ Anaesth 1996; 76: 154-5.

4 Rautoma P, Svartling N. Smoking increases the requirement for rocuronium. Can J Anaesth 1998; 45: $651-4$.

5 Latorre F, de Almeida MCS, Stanek S, Kleemann PP. Effects of smoking on rocuronium neuromuscular blockade. (German). Anaesthesist 1997; 46: 493-5.

6 Rowaan CJ, Vandenbrom RHG, Wierda JMKH The relaxometer: a complete and comprehensive computercontrolled neuromuscular transmission measurement system developed for clinical research on muscle relaxants. J Clin Monit 1993; 9: 38-44. 